\title{
Air Pollution and Respiratory Health Among Men Exposed to Two Different Environs as Occupational Exposure
}

\author{
Adnan Shahzad', Zia Ul Ain Sabiha², Mohsina Haq ${ }^{3}$, Hamad Ullah', \\ Muhammad Hamza Zafar ${ }^{1}$, Salma Khalid ${ }^{4 *}$ \\ ${ }^{1}$ Peshawar Medical College, Prime Foundation, Riphah International University, Islamabad- 25120, Pakistan \\ ${ }^{2}$ Department of Community Health Sciences, Peshawar Medical College, Prime Foundation, \\ Riphah International University, Islamabad- 25120, Pakistan \\ ${ }^{3}$ Department of Pathology, Peshawar Medical College, Prime Foundation, Riphah International University, \\ Islamabad- 25120, Pakistan \\ ${ }^{4}$ Prime Institute of Public Health, Prime Foundation, Riphah International University, Islamabad- 25120, Pakistan
}

Received: 27 February 2020

Accepted: 16 May 2020

\begin{abstract}
Air pollution, a major environmental problem has a direct association with the incidence of respiratory symptoms and decreased in pulmonary function. A comparative cross sectional study was designed for 284 healthy men exposed into two different environs i.e. urban and rural areas of district Peshawar. This study also determined and compared risk factors i.e. men working in open shops for $\sim$ one year or more than one year prior to the study and daily exposure for $\sim 8$ hours per day and lung functions using peak expiratory flow (PEF) measurements. The results showed high significant prevalence $(\mathrm{p}<0.05)$ for bronchitis $83.1 \%(\mathrm{OR}=29.33 ; 95 \% \mathrm{CI}=14.9-54.0)$ and asthma $66.2 \%$ $(\mathrm{OR}=13.5 ; 95 \% \mathrm{CI}=7.5-25.1)$ symptoms in urban area shopkeepers as compared to rural area shopkeepers $14.8 \%$ and $12.7 \%$ respectively. Similarly, the readings of PEF were found severe in $33 \%$, mild in $32 \%$ and normal range in $35 \%$ in urban participants as compared to the shopkeepers living in the rural areas in which severe cases were reported in $13 \%$, mild $19 \%$ and normal $68 \%$ respectively. Exposure per day, per year and more than one year as occupational stay at the shops of men, puts them at greater risk due to their continuous exposure to air pollution. The observed rise in health issues seems to be related with continuous increase in urbanization, traffic emissions and road expansion in the urban area.
\end{abstract}

Keywords: air pollution, occupational exposure, respiratory symptoms, risk factors, peak expiratory flow meter, Peshawar

*e-mail: anagalious_79@yahoo.com 


\section{Introduction}

Air pollution an important environmental risk factor having undeniable impacts on health as directly linked with the prevalence of respiratory disorders and reduced lung function [1]. The published studies revealed that respiratory disorders from short term allergies to long term chronic illnesses are all due to polluted air [24]. The major sources of air pollution are emissions from vehicular traffic, industries, utility, construction activity, and fossil-fuel burning [5-7]. According to the report of World Health Organization (WHO) [8], "approximately, $91 \%$ of the world population were breathing low quality air than the WHO guideline". Most of the megacities of the world including Peshawar has these sources present in their environs and WHO reported [8], it is the $2^{\text {nd }}$ most polluted city among 3000 cities across the world. Rapid expansion in population, urbanization as well as increase in number of vehicles over the last decade and never ending road expansion project (BRT) has intensified the pollution level more in the region.

In many studies, particularly, vehicular emissions has been considered a major source of air pollution in urban areas [9] and almost $\sim 10 \%$ of the respiratory infections may be attributed to urban air pollution [10]. According to a United Nations (UN) report, vehicular emissions contributed more than $60 \%$ of all the substances in air pollution in cities. These harmful substances include: particulates matter $\left(\mathrm{PM}_{10}, \mathrm{PM}_{2.5}\right)$, carbon monoxide $(\mathrm{CO})$, nitrogen oxides $\left(\mathrm{NO}_{\mathrm{x}}\right)$, oxides of sulphur $\left(\mathrm{SO}_{\mathrm{x}}\right)$, tropospheric ozone $\left(\mathrm{O}_{3}\right)$ and so on. These components have been proven as causative factors for different respiratory and cardiovascular pathology [11]. Among these substances, $\mathrm{NO}_{x}$ can do great harm to the environment and human's health [12]. Nitta et al, [13] and Sekine et al, [14] have proved in their studies that exposure to heavy road traffic was related to increased risks of respiratory symptoms, with higher concentration of $\mathrm{NO}_{\mathrm{x}}$ being one of the causes. Similarly, exposure to atmospheric pollutants can cause bronchitis and may even worsen asthma.

Balashanmugam et al. [15] have conducted research on transport workers and reported a striking association between a series of respiratory disorders like irritation of lungs, bronchial asthma and chronic obstructive pulmonary diseases (COPD) and long term exposure to higher concentrations of vehicular emissions like $\mathrm{CO}$, $\mathrm{NO}_{\mathrm{x}}$ and SOx. Furthermore, noteworthy toxicological evidence was determined by Larsson et al. [16], on the effects of traffic-mixture exposures like adults exposed for two hours in a road tunnel with numbers of respiratory symptoms, decreased peak expiratory flow and an inflammatory response in the upper airways in mild asthmatic adults.

Similarly, another aspect of air pollution and a majority of respiratory issues among humans in published literature is new road construction and its consequent operation [17]. Dust and other air pollutants from demolition and construction have greatly impact the health and quality of life of people working on and living close nearby $[18,19]$.

Although, there are a number of sources regarding the ambient air quality and symptoms of respiratory health in children worldwide [20-24], there are very few studies present on adults respiratory health, inside of the specific occupational settings [25]. The occupational exposure and inhalation play a great role in the incidence and exacerbation of respiratory symptoms i.e. bronchitis and chronic asthma but very little is known about their causes like inhaling injurious and poisonous substances from the physical environment, such as air during long time outdoor stay [26-28].

People stay for a long time as occupational exposure particularly by the road sides, often face respiratory symptoms such as shortness of breath, cough, nose congestion, sore throat, phlegm, occupational asthma, cardiovascular problems and so on due to exposure to vehicular emissions of numerous air pollutants [29, 30]. The study of García et al, [31] depicts the same results in traffic-police as occupationally exposed to air pollution had an increased risk of developing respiratory symptoms and signs.

A review study conducted by Schwela and Dieter [32], in 25 Sub African countries depicts that the implications of air pollution on human health are more but unfortunately, very rarely assessed. While, the burden associated with health hazards are reported to continuously rise every year in the developing countries [33].

Likewise, very few studies have been conducted in Peshawar, Pakistan, to evaluate the ill effects of air pollution due to road traffic emission and existing road expansion among urban as well as in rural populations. Peshawar is progressively converting into a city of congestion and traffic; due to growing number of vehicles coupled with expansion in the existing road network.

The use of several transportation activities, construction of roads and overhead bridges has badly affected the atmosphere of this region. Thus, it is necessary to assess and compare the risk factors and pulmonary function among men exposed to urban air at least one year exposure with men of rural area. Understanding the differences in risk factors in various environments can help to illuminate variances in the incidence of these effects/outcomes and can be used to develop and improve public health programs, interventions, and policies.

\section{Materials and Methods}

\section{Study Design and Participants}

A comparative cross sectional study was carried out through randomized survey among 284 healthy men 
in urban and rural areas of district Peshawar. Urban and rural areas were selected as to reflect different environments of exposed and unexposed groups to air pollution. Table 1 shows the details on inclusion and exclusion criteria. The study was approved by the institutional medical ethics committee.

\section{Sample Size}

Sample size calculation was carried out through Daniel [34] biostatistics calculator which is mainly used in health sciences for prevalence studies.

$$
\begin{aligned}
& n^{\prime}=\frac{N Z^{2} P(1-P)}{d^{2}(N-1)+Z^{2} P(1-P)} \\
& \text { where } n^{\prime}=\text { Sample size with finite population correction, } \\
& N=\text { Population size } \\
& Z=Z \text { statistic for a level of confidence, } \\
& P=\text { Expected proportion (If the prevalence is } 20 \%, P=0.2 \text { ), and } \\
& d=\text { Precision (If the precision is } 5 \% \text {, then } d=0.05 \text { ) }
\end{aligned}
$$

Sample size $=142$ participants from urban area and 142 from rural area

\section{Data Collection}

Data collection comprised two steps; questionnaire survey and peak flow meter measurements. The data was collected through modified SAPALDIA structured questionnaire during September to November, 2019. Comprising of the personal information and details related to the clinical history of the total surveyed population i.e. $\mathrm{n}=284$. Especially, the shopkeepers were identified as the main target group for both urban and rural areas, as they reside daily in high exposure area for a maximum period of time. The presence of respiratory symptoms in the studied population (shopkeepers) were confirmed by questions commonly related to the diagnosis of bronchitis and asthma symptoms like cough, chronic phlegm, chronic cough/ phlegm and wheezing without cold, breathlessness during the day/night, current asthma, dyspnea on exertion and chest tightness respectively.
Table 2. Wright's peak flow meter zones.

\begin{tabular}{|c|c|c|}
\hline Zones & Reading & Indications \\
\hline $\begin{array}{c}\text { Green zone } \\
\text { (Normal) }\end{array}$ & $\begin{array}{c}80 \text { to } \\
100 \%\end{array}$ & Normal peak flow readings \\
\hline $\begin{array}{c}\text { Yellow zone } \\
\text { (Mild) }\end{array}$ & $\begin{array}{c}50 \text { to } \\
79 \%\end{array}$ & $\begin{array}{c}\text { Indicates caution. It may } \\
\text { mean respiratory airways are } \\
\text { narrowing }\end{array}$ \\
\hline $\begin{array}{c}\text { Red zone } \\
\text { (Severe) }\end{array}$ & $\begin{array}{c}\text { Less than } \\
50 \%\end{array}$ & $\begin{array}{c}\text { Indicates a medical } \\
\text { emergency and severe airway } \\
\text { narrowing }\end{array}$ \\
\hline
\end{tabular}

Pulmonary function was tested through Wright's peak flow meter after obtaining the consent from the surveyed population. Peak flow score is displayed on the side of peak flow meter. This is given in liters of air breathed out per minute $(1 / \mathrm{min})$. Peak flow readings are often classified into 3 zones of measurement according to the American Lung Association [35]; green, yellow, and red (Table 2).

\section{Data Analysis}

Statistical analysis was carried out through SPSS version 22. Descriptive analysis using simple frequencies and percentages. Univariate relationship between two categorical variables tested with chi-square. Multiple logistic regressions were also performed to test the association between exposure to outdoor ambient air pollution per day, year and more than one year as occupational stay at the shops of men and its risk factor. Odd ratios and the corresponding 95\% confidence intervals were also computed. Variables with $\mathrm{p}$ value less than 0.05 were considered significantly associated with presence of bronchitis and asthma symptoms.

\section{Results and Discussion}

The total response rate was $100 \%$. The overall bronchitis and asthma prevalence identified in this

Table 1. Inclusion and exclusion criteria.

\begin{tabular}{|c|c|}
\hline Inclusion criteria & Exclusion criteria \\
\hline $\begin{array}{c}\text { Preferably, men having work history along the main road side } \\
\text { such as shopkeepers }\end{array}$ & $\begin{array}{c}\text { Having past or present history of respiratory diseases such as } \\
\text { asthma, tuberculosis and other Chronic Obstructive Pulmonary } \\
\text { Diseases }\end{array}$ \\
\hline Age 30-50 years & Incomplete filling of the questionnaire \\
\hline $\begin{array}{c}\text { Morking in open shops for at least one year or more than one } \\
\text { year prior to the study }\end{array}$ & \\
\hline Spend almost eight or more than eight hours on the shop daily & \\
\hline No history of respiratory disorders & \\
\hline No smoking & \\
\hline
\end{tabular}


Table 3. Presence of respiratory symptoms among shopkeepers of urban and rural areas.

\begin{tabular}{|c|c|c|c|c|c|c|}
\hline \multirow{2}{*}{\multicolumn{2}{|c|}{ Respiratory Symptoms }} & \multicolumn{2}{|c|}{ Groups } & \multirow{2}{*}{$\begin{array}{l}\text { Odds ratio } \\
\text { (OR) }\end{array}$} & \multirow{2}{*}{$\begin{array}{c}\text { Significance } \\
\text { ( } p \text {-value) }\end{array}$} & \multirow{2}{*}{$95 \% \mathrm{CI}$} \\
\hline & & Urban n (\%) & Rural n (\%) & & & \\
\hline \multirow{2}{*}{ Bronchitis } & Present & $118(83.1 \%)$ & $21(14.8 \%)$ & \multirow{2}{*}{29.33} & \multirow{2}{*}{$0.0001 * *$} & \multirow{2}{*}{$14.9-54.0$} \\
\hline & Not present & $24(16.9 \%)$ & $121(85.2 \%)$ & & & \\
\hline \multirow{2}{*}{ Asthma } & Present & $94(66.2 \%)$ & $18(12.7 \%)$ & \multirow{2}{*}{13.5} & \multirow{2}{*}{$0.000^{* *}$} & \multirow{2}{*}{$7.5-25.1$} \\
\hline & Not present & $48(33.8 \%)$ & $124(87.3 \%)$ & & & \\
\hline
\end{tabular}

Table 4. Risk factors for respiratory symptoms in men exposed into two different environs.

\begin{tabular}{|c|c|c|c|c|c|c|c|c|c|c|}
\hline Symptoms & Groups & \multicolumn{2}{|c|}{ Variables } & $\begin{array}{c}\text { No. of } \\
\text { participants } \\
(+)\end{array}$ & $\begin{array}{c}\text { No. of } \\
\text { participants } \\
(-)\end{array}$ & Row totals & $\begin{array}{l}\text { Odds } \\
\text { ratio } \\
(\mathrm{OR})\end{array}$ & $\begin{array}{c}\text { Chi - } \\
\text { square } \\
\text { statistics }\end{array}$ & p-value & $\begin{array}{c}95 \%- \\
\text { CI }\end{array}$ \\
\hline \multirow{12}{*}{ Bronchitis } & \multirow{3}{*}{ Urban } & \multirow{6}{*}{$\begin{array}{c}\text { Daily } \\
\text { exposure }\end{array}$} & $8 \mathrm{hr} /$ day & 50 & 16 & 66 & \multirow{3}{*}{0.3676} & \multirow{3}{*}{4.7317} & \multirow{3}{*}{$.029 * *$} & \multirow{3}{*}{$\begin{array}{l}0.146- \\
0.9261\end{array}$} \\
\hline & & & $>8 \mathrm{hr} /$ day & 68 & 8 & 76 & & & & \\
\hline & & & $\begin{array}{c}\text { Column } \\
\text { totals }\end{array}$ & 118 & 24 & $\begin{array}{c}142 \\
\text { (Grand Total) }\end{array}$ & & & & \\
\hline & \multirow{3}{*}{ Rural } & & 8hr/day & 4 & 21 & 25 & \multirow{3}{*}{1.12} & \multirow{3}{*}{0.0353} & \multirow{3}{*}{0.85} & \multirow{3}{*}{$\begin{array}{l}0.3421- \\
3.67\end{array}$} \\
\hline & & & $>8 \mathrm{hr} /$ day & 17 & 100 & 117 & & & & \\
\hline & & & $\begin{array}{c}\text { Column } \\
\text { totals }\end{array}$ & 21 & 121 & $\begin{array}{c}142 \\
\text { (Grand Total) }\end{array}$ & & & & \\
\hline & \multirow{3}{*}{ Urban } & \multirow{6}{*}{$\begin{array}{c}\text { Occu- } \\
\text { pational } \\
\text { exposure }\end{array}$} & 1year & 84 & 7 & 91 & \multirow{3}{*}{6} & \multirow{3}{*}{15.2995} & \multirow{3}{*}{$0.000 * * *$} & \multirow{3}{*}{$\begin{array}{l}2.283- \\
15.77\end{array}$} \\
\hline & & & $>1$ year & 34 & 17 & 51 & & & & \\
\hline & & & $\begin{array}{l}\text { Column } \\
\text { totals }\end{array}$ & 118 & 24 & $\begin{array}{c}142 \\
\text { (Grand Total) }\end{array}$ & & & & \\
\hline & \multirow{3}{*}{ Rural } & & 1year & 2 & 12 & 14 & \multirow{3}{*}{0.9804} & \multirow{3}{*}{0.0031} & \multirow{3}{*}{0.95} & \multirow{3}{*}{$\begin{array}{c}0.2014- \\
4.773\end{array}$} \\
\hline & & & $>$ lyear & 17 & 100 & 117 & & & & \\
\hline & & & $\begin{array}{l}\text { Column } \\
\text { totals }\end{array}$ & 21 & 121 & $\begin{array}{c}142 \\
\text { (Grand Total) }\end{array}$ & & & & \\
\hline \multirow{12}{*}{ Asthma } & \multirow{3}{*}{ Urban } & \multirow{6}{*}{$\begin{array}{c}\text { Daily } \\
\text { exposure }\end{array}$} & $8 \mathrm{hr} /$ day & 18 & 18 & 36 & \multirow{3}{*}{0.3947} & \multirow{3}{*}{5.6542} & \multirow{3}{*}{$0.02 * *$} & \multirow{3}{*}{$\begin{array}{r}0.1813- \\
0.8594\end{array}$} \\
\hline & & & $>8 \mathrm{hr} /$ day & 76 & 30 & 106 & & & & \\
\hline & & & $\begin{array}{l}\text { Column } \\
\text { totals }\end{array}$ & 94 & 48 & 142 & & & & \\
\hline & & & $8 \mathrm{hr} /$ day & 3 & 22 & 25 & & & & \\
\hline & Rural & & $>8 \mathrm{hr} /$ day & 15 & 102 & 117 & 0.9273 & 0.0125 & 0.91 & $0.2471-$ \\
\hline & & & $\begin{array}{c}\text { Column } \\
\text { totals }\end{array}$ & 18 & 124 & 142 & & & & \\
\hline & & & 1year & 26 & 28 & 54 & & & & \\
\hline & Urban & & $>1$ year & 68 & 20 & 88 & 0.2731 & 12.6857 & $0.000 * *$ & $0.1316-$ \\
\hline & & Occu- & $\begin{array}{l}\text { Column } \\
\text { totals }\end{array}$ & 94 & 48 & 142 & & & & 0.5009 \\
\hline & & exposure & 1year & 2 & 12 & 14 & & & & \\
\hline & Rural & & >1year & 16 & 112 & 128 & 1.167 & 0.0364 & 0.84 & $0.2389-$ \\
\hline & & & $\begin{array}{l}\text { Column } \\
\text { totals }\end{array}$ & 18 & 124 & 142 & & & & 5.091 \\
\hline
\end{tabular}


study were slightly higher in urban area shopkeepers $(75.04 \%)$ than that of rural areas $(13.73 \%)$. In rural area, the symptoms of bronchitis and asthma were found in $21(14.8 \%)$ and 18 (12.7\%) study participants, while the symptoms of bronchitis and asthma in urban area, were found in 118 (83.1\%; OR $=29.33 ; 95 \%$ $\mathrm{CI}=14.9-54.0)$ and $94(66.2 \% ; \mathrm{OR}=13.5 ; 95 \%$ $\mathrm{CI}=7.5-25.1)$ participants respectively. Comparatively, the symptoms of bronchitis and asthma were found significant $(\mathrm{p}<0.05)$ in urban areas as shown in the Table 3.

According to the studies of Gurung and Bell [10], Nicoll and Henein [36], these respiratory illnesses are largely attributed to the particulate matter like dust, soot, smoke and different toxic chemicals present in the air [10]. According to the WHO [8] report, majority of Southeast Asia countries are experiencing high levels of air pollution, especially in urban areas where the annual mean levels often exceed limits 5-10 fold.

A study conducted by Ali et al. [37] in the Rawalpindi city of Pakistan has revealed significant association of health issues with the inhalation of road traffic on daily basis among roadside workers $(n=580)$. The results revealed that $\sim 80 \%$ of the surveyed population have high risks of asthma $(\mathrm{OR}=32.84$; $95 \%$ - CI $=15.59-69.15)$, cardiovascular symptoms $(\mathrm{OR}=13.8 ; 95 \%-\mathrm{CI}=3.63-52.41)$ and caused increased rate of hospitalization over times. The observed rise in air pollutants and associated health issues seems to be related with continuously increased urbanization, industries and traffic in the urban areas of Rawalpindi $[4,38]$. Similarly, the present study findings are similar with the study of Ilyas et al, [39] conducted in the urban areas of Quetta, Pakistan. The status of air pollution in Quetta city is found to be very life threatening and its consequences on human health arising due to presence of high concentration of particulate matter in the area. The particulate matter, particularly less than $10 \mathrm{~mm}$ in size, can pass through the natural protective mechanism of human respiratory system and plays an important role in genesis and augmentation of allergic disorders as well as respiratory disorders [39]. Furthermore similar findings have been mirrored in the study carried out in Jalgaon urban center of India. In this research, the impact of vehicular pollution on human health in urban areas is at peak level as vehicle emissions are near the ground level where people live and work. The continuous exposure of the population to these higher levels of air pollutants leads in decrease in the lung capacity.

\section{Risk Factors}

Risk factors such as daily exposure per day $\sim 8$ hours and more than 8 hours and occupational exposure such as one year and more than one year were determined through logistic regression analysis and results were found significant $(p<0.05)$ for shopkeepers in urban area as compared to shopkeepers exposed in rural areas as depicted in Table 4. In urban areas shopkeepers the symptoms of bronchitis were found in $50(35.2 \%)$ and $68(47.8 \%)$ participants for daily work exposure with odds ratio 0.34 as compared to the rural areas shopkeepers where it is found only in $4(2.8 \%)$ and $17(12.1 \%)$ numbers of participants with odds ratio 1.12 respectively (Table 4). Similarly in occupational exposure high value of bronchitis symptoms were noted in urban shopkeepers i.e. $84(59.2 \%)$ and 34 (23.9\%) numbers of participants while in rural shopkeepers this was found only in 2 (1.4\%) and 17 (12.1\%) participants. Furthermore, the asthma symptoms were found increased with increasing exposure like in 18 $(12.7 \%)$ and $76(53.5 \%)$ participants for daily stay on the shop and $26(18.3 \%)$ and $68(48.1 \%)$ in participants for occupational stay with most significant $p$-value $(\mathrm{p}<0.05)$.

Several studies, for example have reported a substantial increase in the prevalence of the respiratory illness among workers of different occupations with apparent positive association with air pollution and occupational exposure [27, 40-45].

\section{Measurements of Peak Flow Meter}

Likewise the symptoms of respiratory disorders, measurements of peak flow meter were found significantly different $(\mathrm{p}<0.05)$ from rural area through Pearson's chi square test. In urban area the readings of PEF were found severe in $47(33 \%)$, mild in 46

\section{URBAN AREA SHOPKEEPERS}

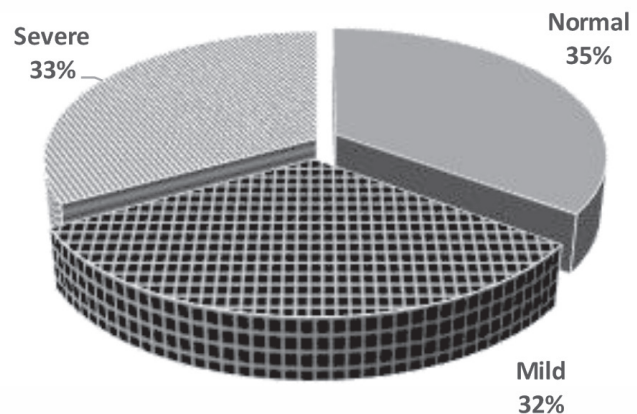

RURAL AREASHOPKEEPERS

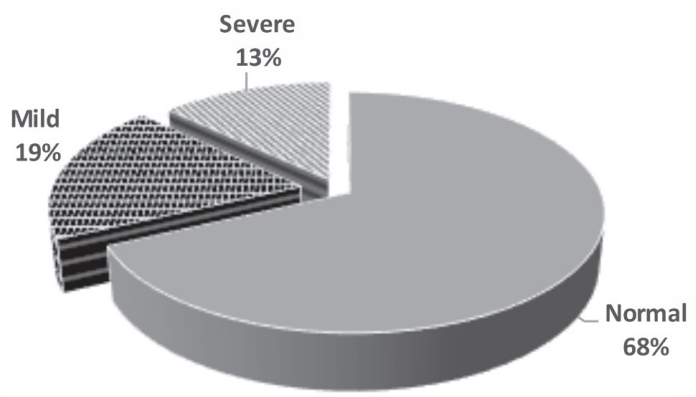

Fig 1. No. of studied participants through peak flow reading according to 3 zones of measurement. 
$(32 \%)$ and normal range in $49(35 \%)$ participants as compared to the shopkeepers living in the rural areas in which severe cases were reported in $18(13 \%)$, mild 27 (19\%) and normal 97 (68\%) respectively (Fig. 1).

Also PFR readings among urban area shopkeepers were recorded $47(33 \%)$, mild in $46(32 \%)$ participants with increase in duration of their stay on shop which was statistically significant $(\mathrm{p}<0.05)$. Similar findings by Prakash et al, [46] showed a fall in pulmonary lung function among shopkeepers who work in places near highways and were exposed to high levels of air pollution compared to the control group. However, these workers were also taking the least preventive measures to save their selves from exposure to air pollution. The alarming rise in particulate matter concentrations among Asian countries indeed poses severe threats to locals (street vendors and small business entrepreneurs) that work in these environments without proper precautions $[47,48]$

\section{Conclusion}

There is no doubt that Peshawar is facing rapid population growth, increased number of vehicles as well as traffic congestion and roads construction and expansion activities like other mega cities in the world. The study results have clearly shown that men exposed to urban air are more prone to bronchitis and asthma as compare to the rural area of Peshawar. Exposure per day, per year and more than one year as occupational nature/stay at the shops of men, puts them at greater risk due to their continuous exposure to air pollution. Therefore, it is recommended that Government should develop a control strategy for air pollution. Otherwise, they have huge economic impacts by decreasing productivity, increasing healthcare expenditure, morbidity and mortality. In addition, awareness programs should be arranged to educate the shopkeepers about ill effects of air pollution and encouraged them to use protective masks and make habit of regular health checkup. Further, with little modification in data, prospective studies should be conducted in a number of geographical areas to examine current urban air pollution and associated incidence of respiratory disorders.

\section{Acknowledgements}

The authors sincerely thank all the participants who were involved in the study.

\section{Conflict of Interest}

The authors declare no conflict of interest.

\section{References}

1. RUIZ S, ARRUTI A, FERNÁNDEZ-OLMO I, IRABIEN J. Contribution of point sources to trace metal levels in urban areas surrounded by industrial activities in the Cantabria region (northern Spain). Procedia Environmental Sciences. 4, 76, 2011.

2. CHEN Z., SALAM M.T., ECKEL S.P., BRETON C.V., GILLILAND F.D. Chronic effects of air pollution on respiratory health in Southern California children: findings from the Southern California Children's Health Study. Journal of thoracic disease. 7 (1), 46, 2015.

3. WHO. Ambient (outdoor) air quality and health. 2014.

4. SIMONI M., BALDACCI S., MAIO S., CERRAI S., SARNO G., VIEGI G. Adverse effects of outdoor pollution in the elderly. Journal of thoracic disease. 7 (1), 34, 2015.

5. BI X., LIANG S., LI X. A novel in situ method for sampling urban soil dust: particle size distribution, trace metal concentrations, and stable lead isotopes. Environmental pollution. 177, 48, 2013.

6. KURMI O., REGMI P.R., PANT P.R. Implication of air pollution on health effects in Nepal: lessons from global research. Nepal journal of epidemiology. 6 (1), 525, 2016.

7. SVECOVA V., TOPINKA J., SOLANSKY I., ROSSNER JR P., SRAM R.J. Personal exposure to carcinogenic polycyclic aromatic hydrocarbons in the Czech Republic. Journal of Exposure Science and Environmental Epidemiology. 23 (4), 350, 2013.

8. WHO. Air quality and Health 2014. WHO: Geneva, Switzerland.2018.

9. SUN C., LUO Y., LI J. Urban traffic infrastructure investment and air pollution: Evidence from the 83 cities in China. Journal of cleaner production. 172, 488, 2018.

10. GURUNG A., BELL M.L. The state of scientific evidence on air pollution and human health in Nepal. Environmental Research. 124, 54, 2013.

11. UZOIGWE J.C., PRUM T., BRESNAHAN E., GARELNABI M. The emerging role of outdoor and indoor air pollution in cardiovascular disease. North American journal of medical sciences. 5 (8), 445, 2013.

12. DHONDT S., BECKX C., DEGRAEUWE B., LEFEBVRE W., KOCHAN B., BELLEMANS T., PANIS L.I., MACHARIS C., PUTMAN K. Health impact assessment of air pollution using a dynamic exposure profile: implications for exposure and health impact estimates. Environmental impact assessment review. 36, 42, 2012.

13. NITTA H., SATO T., NAKAI S., MAEDA K., AOKI S., ONO M. Respiratory health associated with exposure to automobile exhaust. I. Results of cross-sectional studies in 1979, 1982, and 1983. Archives of Environmental Health: An International Journal. 48 (1), 53, 1993.

14. SEKINE K., SHIMA M., NITTA Y., ADACHI M. Long term effects of exposure to automobile exhaust on the pulmonary function of female adults in Tokyo, Japan. Occupational and Environmental Medicine. 61 (4), 350, 2004.

15. BALASHANMUGAM P., RAMANATHAN A., KUMAR V.N. Ambient air quality monitoring in Puducherry. International Journal of Engineering Research and Applications. 2 (2), 300, 2012.

16. LARSSON B.-M., GRUNEWALD J., SKÖLD C.M., LUNDIN A., SANDSTRÖM T., EKLUND A., SVARTENGREN M. Limited airway effects in mild asthmatics after exposure to air pollution in a road tunnel. Respiratory medicine. 104 (12), 1912, 2010. 
17. FONT A., BAKER T., MUDWAY I.S., PURDIE E., DUNSTER C., FULLER G.W. Degradation in urban air quality from construction activity and increased traffic arising from a road widening scheme. Science of the Total Environment. 497, 123, 2014.

18. BERGDAHL I., TOREN K., ERIKSSON K., HEDLUND U., NILSSON T., FLODIN R., JÄRVHOLM B. Increased mortality in COPD among construction workers exposed to inorganic dust. European Respiratory Journal. 23 (3), 402, 2004.

19. KUMAR P., MULHERON M., SOM C. Release of ultrafine particles from three simulated building processes. Journal of Nanoparticle Research. 14 (4), 771, 2012.

20. HOEK G., PATTENDEN S., WILLERS S., ANTOVA T., FABIANOVA E., BRAUN-FAHRLÄNDER C., FORASTIERE F., GEHRING U., LUTTMANNGIBSON H., GRIZE L. PM10, and children's respiratory symptoms and lung function in the PATY study. European Respiratory Journal. 40 (3), 538, 2012.

21. MANN J.K., BALMES J.R., BRUCKNER T.A., MORTIMER K.M., MARGOLIS H.G., PRATT B., HAMMOND S.K., LURMANN F.W., TAGER I.B. Shortterm effects of air pollution on wheeze in asthmatic children in Fresno, California. Environmental health perspectives. 118 (10), 1497, 2010.

22. NISHIMURA K.K., GALANTER J.M., ROTH L.A., OH S.S., THAKUR N., NGUYEN E.A., THYNE S., FARBER H.J., SEREBRISKY D., KUMAR R. Early-life air pollution and asthma risk in minority children. The GALA II and SAGE II studies. American journal of respiratory and critical care medicine. 188 (3), 309, 2013.

23. SAMOLI E., NASTOS P., PALIATSOS A., KATSOUYANNI K., PRIFTIS K. Acute effects of air pollution on pediatric asthma exacerbation: evidence of association and effect modification. Environmental Research. 111 (3), 418, 2011.

24. BARBOSA S.M.D.M., FARHAT S.C.L., MARTINS L.C., PEREIRA L.A.A., SALDIVA P.H.N., ZANOBETTI A., BRAGA A.L.F. Air pollution and children's health: sickle cell disease. Cadernos de saude publica. 31, 265, 2015.

25. JACQUEMIN B., SCHIKOWSKI T., CARSIN A.E., HANSELL A., KRÄMER U., SUNYER J., PROBSTHENSCH N., KAUFFMANN F., KÜNZLI N. editors. The role of air pollution in adult-onset asthma: a review of the current evidence. Seminars in respiratory and critical care medicine; 2012: Thieme Medical Publishers. Published, Year.

26. ANDERSON T.J., SAMAN D.M., LIPSKY M.S., LUTFIYYA M.N. A cross-sectional study on health differences between rural and non-rural US counties using the County Health Rankings. BMC health services research. 15 (1), 441, 2015.

27. BLANC P.D., ANNESI-MAESANO I., BALMES J.R., CUMMINGS K.J., FISHWICK D., MIEDINGER D., MURGIA N., NAIDOO R.N., REYNOLDS C.J., SIGSGAARD T. The Occupational Burden of Nonmalignant Respiratory Diseases. An Official American Thoracic Society and European Respiratory Society Statement. American journal of respiratory and critical care medicine. 199 (11), 1312, 2019.

28. ZHANG X., HOLT J.B., LU H., ONUFRAK S., YANG J., FRENCH S.P., SUI D.Z. Neighborhood commuting environment and obesity in the United States: An urbanrural stratified multilevel analysis. Preventive medicine. 59, 31, 2014.
29. NKHAMA E., NDHLOVU M., DVONCH J.T., SIZIYA S., VOYI K. Prevalence and determinants of mucous membrane irritations in a community near a cement factory in Zambia: A Cross Sectional Study. International journal of environmental research and public health. 12 (1), 871, 2015.

30. WEST S.K., BATES M.N., LEE J.S., SCHAUMBERG D.A., LEE D.J., ADAIR-ROHANI H., CHEN D.F., ARAJ H. Is household air pollution a risk factor for eye disease? International journal of environmental research and public health. 10 (11), 5378, 2013.

31. GARCÍA J., ROJAS-ROA N.Y., RODRÍGUEZ-PULIDO A.I. Occupational exposure to air pollutants: particulate matter and respiratory symptoms affecting traffic-police in Bogotá. Revista de salud publica. 15, 870, 2013.

32. SCHWELA, DIETER. Review of Urban Air Quality in Sub-Saharan Africa Region: Air Quality Profile of SSA Countries. World Bank, 2012.

33. HEI. Outdoor air pollution and health in the developing countries of Asia: a comprehensive review. Special report 18. 2010.

34. DANIEL W. The repeated measures design. Biostatistics: a foundation for analysis in the health sciences 7th ed New York: John Wiley \& Sons: 334, 1999.

35. AMERICAN LUNG ASSOCIATION. How can I determine a normal peak flow rate for me? 2007.

36. NICOLL R., HENEIN M. Air pollution and its cardiovascular and other risks. Journal of internal medicine. 271 (5), 429, 2012.

37. ALI M.U., RASHID A., YOUSAF B., KAMAL A. Health outcomes of road-traffic pollution among exposed roadside workers in Rawalpindi City, Pakistan. Human and Ecological Risk Assessment: An International Journal. 23 (6), 1330, 2017.

38. SHAH M.H., SHAHEEN N. Statistical analysis of atmospheric trace metals and particulate fractions in Islamabad, Pakistan. Journal of hazardous materials. 147 (3), 759, 2007.

39. ILYAS S.Z., KHATTAK A.I., NASIR S., QURASHI T., DURRANI R. Air pollution assessment in urban areas and its impact on human health in the city of Quetta, Pakistan. Clean Technologies and Environmental Policy. 12 (3), 291, 2010.

40. KARKI P.K., KHAREL S., KHAKUREL G., TIWARI N. Effect of Air Pollutants on Peak Expiratory Flow Rate of Public Bus Drivers in Bhaktapur, Nepal. Journal of College of Medical Sciences-Nepal. 15 (1), 30, 2019.

41. AGGARWAL A., CHAUDHRY K., CHHABRA S., D SOUZA G., GUPTA D., JINDAL S., KATIYAR S., KUMAR R., SHAH B., VIJAYAN V. Prevalence and risk factors for bronchial asthma in Indian adults: a multicentre study. Indian Journal of chest diseases and allied sciences. 48 (1), 13, 2006.

42. JIŘÍK V., DALECKÁ A., VAŠENDOVÁ V., JANOUTOVÁ J., JANOUT V. How serious are health impacts in one of the most polluted regions of Central Europe? Reviews on environmental health. 32 (1-2), 177, 2017.

43. HOY R.F., BURGESS J.A., BENKE G., MATHESON M., MORRISON S., GURRIN L., WALTERS E.H., DHARMAGE S.C., ABRAMSON M.J. Occupational exposures and the development of new-onset asthma: a population-based cohort study from the ages of 13 to 44 years. Journal of occupational and environmental medicine. 55 (3), 235, 2013.

44. LILLIENBERG L., ANDERSSON E., JANSON C., DAHLMAN-HÖGLUND A., FORSBERG B., HOLM M., 
GĹSLASON T., JÖGI R., OMENAAS E., SCHLÜNSSEN $\mathrm{V}$. Occupational exposure and new-onset asthma in a population-based study in Northern Europe (RHINE). Annals of Occupational Hygiene. 57 (4), 482, 2012.

45. BAHAUDDIN K.M., UDDIN T.S., editors. Status of particulate matter and its impact on roadside population of Dhaka City, Bangladesh: A review study. Proceeding of international conference on environmental aspects of Bangladesh (ICEAB10), Japan; 2010. Published, Year.

46. PRAKASH A.M., SWAMY A., KRISHNA R.H. Studies on the transport related pollutants in the ambient atmosphere and their health impacts on the road side venders of the Indian city. European Chemical Bulletin. 2 (1), 28, 2012.

47. MAJID H., ALAM K., MADL P., HOFMANN W. Exposure assessment and associated lung deposition calculations for vehicular exhaust in four metropolitan cities of Pakistan. Environmental monitoring and assessment. 185 (6), 5265, 2013.

48. HOPKE P.K., COHEN D.D., BEGUM B.A., BISWAS S.K., NI B., PANDIT G.G., SANTOSO M., CHUNG Y.-S., DAVY P., MARKWITZ A. Urban air quality in the Asian region. Science of the Total Environment. 404 (1), 103, 2008 